\title{
Editorial Introduction to Quantitative Gastronomy
}

The American Association of Wine Economists is pleased to welcome the newly founded Society for Quantitative Gastronomy, whose chef-coq is Olivier Gergaud. The Society has joined the American Association of Wine Economists as its food division. Henceforth, once each year, beginning with this issue, the Journal of Wine Economics will host a symposium on gastronomy.

The first paper is on French and Italian hotel breakfasts. Does "petit déjeuner compris" mean that breakfasts are free? George E. Johnson, who is the keynote speaker at the First Annual Meeting of the American Association of Wine Economists on May 23-26, 2007, in Trier, answers this question and shows that a "free" breakfast increases the room price by as much as $10-15 \%$.

In the second paper, Olivier Gergaud, Linett Montano Guzman, and Vincenzo Verardi take readers on a tour to the best and the worst Paris restaurants. They show how the celebrated Michelin Guide distorts the market for good food. As a practical guide for Paris visitors, their appendix provides a list of the 100 best restaurant deals from an econometrician's perspective.

Readers of the Journal of Wine Economics are familiar with the authors of the third food symposium paper. In the inaugural issue of the Journal, Pierre Combris, Christine Lange and Sylvie Issanchou examined the effect of packaging information on the reservation price of Champagne, and found disturbing results. In this issue, they conduct experiments with consumers of orange juice, and find that choices are rational and consistent, leaving room for speculation.

The editors 